Americans and

Chinese Communists, 1927-1945

$\star$ A PERSUAding encounter

Kenneth E. Shewmaker

Cornell University Press

ITHACA AND LONDON 


\section{Americans and}

\section{Cbinese Communists, 1927-1945}

A PERSUADING ENCOUNTER 


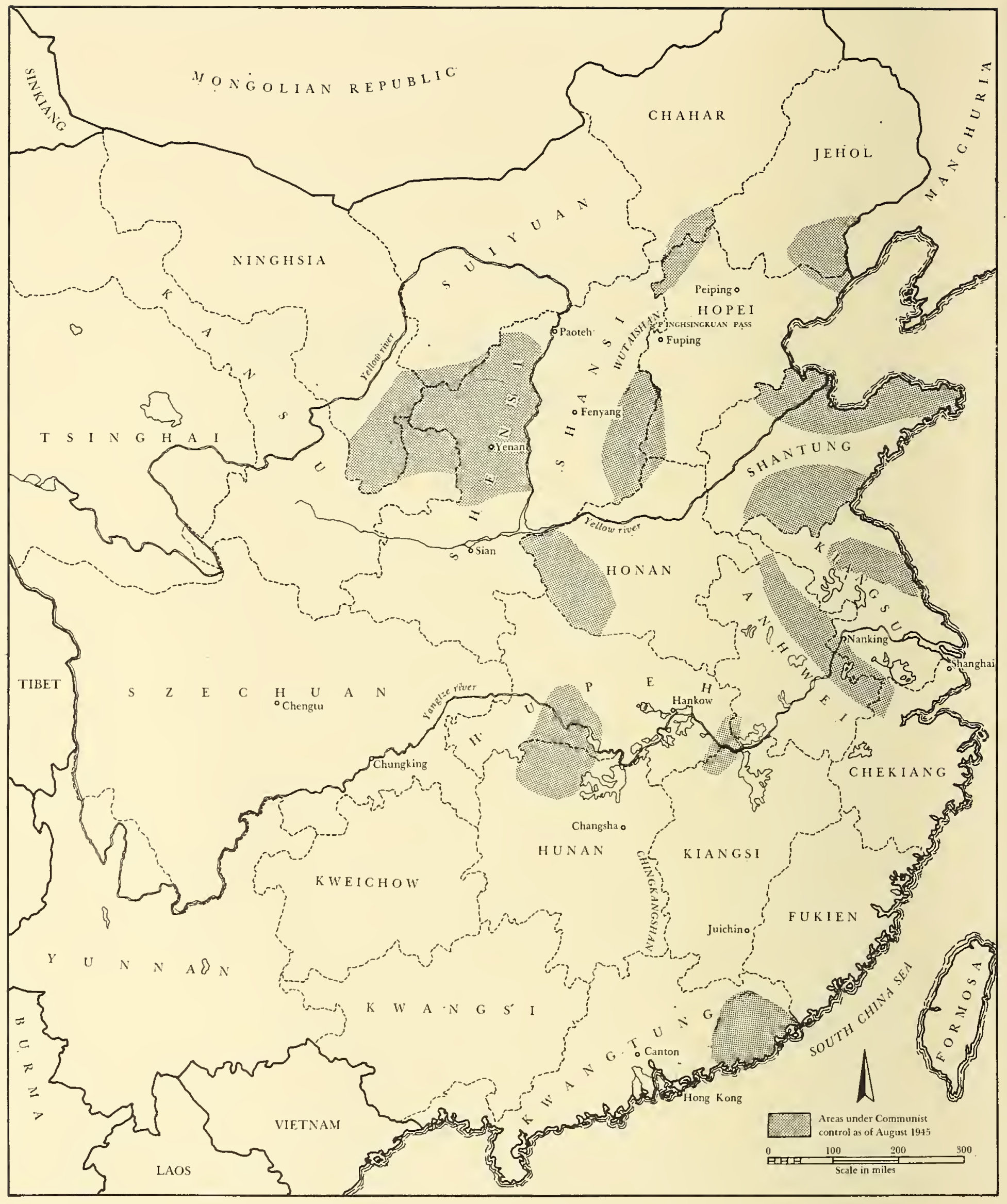

\section{CHINA}




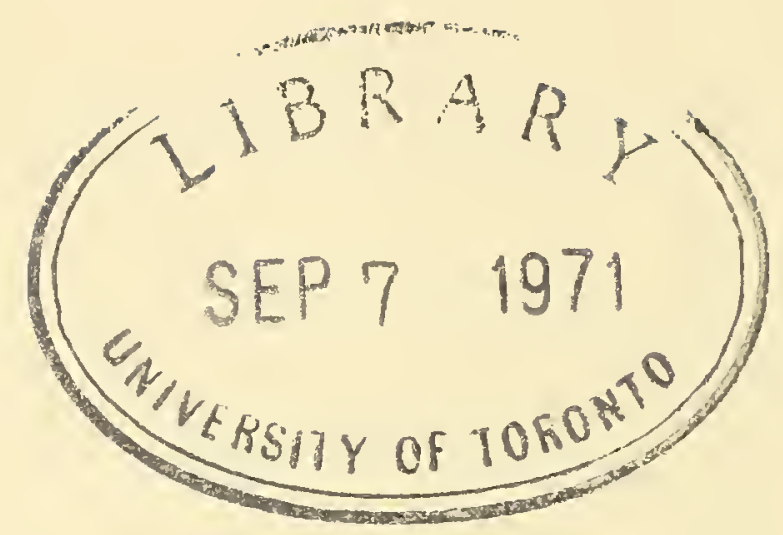

Copyright $(1971$ by Cornell University

All rights reserved. Except for brief quotations in a review, this book, or parts thereof, must not be reproduced in any form without permission in writing from the publisher. For information address Cornell University Press, 124 Roberts Place, Ithaca, New York $1485^{\circ}$.

First published 197 I

International Standard Book Number o-8014-06 $17^{-\mathrm{X}}$ Library of Congress Catalog Card Number 70-144031

PRINTED IN THE UNITED STATES OF AMERICA

BY VAIL-BALLOU PRESS, INC. 


\section{$\mathcal{T}_{0}$ Liese and to \\ Richard W. Leopold}


Digitized by the Internet Archive in 2018 with funding from

The Arcadia Fund 